\title{
К ВОПРОСУ О РОЛИ КОМИССИЙ ПО ДЕЛАМ НЕСОВЕРШЕННОЛЕТНИХ И ЗАЩИТЕ ИХ ПРАВ КАК КООРДИНАТОРА В БОРЬБЕ С ПРЕСТУПНОСТЬЮ НЕСОВЕРШЕННОЛЕТНИХ В СВЕТЕ ДЕЙСТВУЮЩЕГО ЗАКОНОДАТЕЛЬСТВА
}

\section{Коновалова И.А.}

Аннотация. В настоящей статье рассматриваются субъекты профилактики правонарушающего поведения несовершеннолетних; представлены изученные результаты деятельности комиссий по делам несовершеннолетних. Обосновывается необходимость разработки государственной политики предупреждения правонарушений несовершеннолетних, основные положения которой должны получить детальное закрепление в законодательстве. Анализируются основания отнесения комиссии по делам несовершеннолетних и защите их прав к числу государственных органов или к общественным организациям. Рассматриваются полномочия комиссии по делам несовериеннолетних и защите их прав в профилактике социально опасного положения и правонарушения несовершеннолетних. С использованием методов анализа и сравнения проанализированы различные научные подходы к профилактике социально опасного положения и правонарушения несовершеннолетних. В статье делается вывод о том, что процесс становления ювенальной юстиции в РФ не прекратит деятельности комиссий, поскольку их работа не утратит своей актуальности. Правозащитная, координирующая и контролирующая функции комиссии позволят им проводить полное и объективное исследование условий жизни подростков, разрабатывать индивидуальные программы профилактики, осуществлять психологическую диагностику личности несовершеннолетних, содействовать их трудоустройству или получению образования.

Ключевые слова: конвенция, координирующий орган, права ребенка, система профилактики, комиссии, причины и условия, программа профилактики., несобершеннолетние, борьба с преступностью, государственная политика.

Строгое определение круга лиц в теории и практике предупреждения преступности одна из основных задач действующего законодательства, которое на протяжении уже более двадцати лет приводится в соответствие с реальной действительностью.

Для реализации положений ст. 4 Конвенции $\mathrm{OOH}$ «О правах ребенка» и ст. 62 Руководящих принципов в Российской Федерации принимается
Федеральный Закон от 24 июня 1999 г. № 120-Ф3 «Об основах системы профилактики безнадзорности и правонарушений несовершеннолетних» ${ }^{1}$, который определил новые способы решения

\footnotetext{
${ }^{1}$ См.: Федеральный Закон от 24 июня 1999 г. № 120-Ф3 «Об основах системы профилактики безнадзорности и правонарушений несовершеннолетних» // СЗ РФ. 1999. № 26. Ст. 3177.
} 
проблемы предупреждения преступлений несовершеннолетних учитывая рекомендации, содержащиеся в международно-правовых документах.

Во исполнение положений постановления Правительства РФ от 8 октября 1998 г. № 1174 «О Межведомственной комиссии по координации работ, связанных с выполнением в РФ Конвенции ООН о правах ребенка и Всемирной декларации об обеспечении выживания, защиты и развития детей» ${ }^{1}$ создается межведомственный специализированный государственный орган Комиссия, в состав которой были включены представители заинтересованных министерств, ведомств и организаций, однако на практике она не координировала усилия субъектов профилактики подростковой преступности.

Единственным путем решения этой проблемы является разработка государственной политики предупреждения правонарушений несовершеннолетних, основные положения которой должны быть закреплены законодательно. Но все предложения коррекции и развития государственной политики свелись к принятию немалого количества нормативных актов в этой области ограничившись началом 2000 годов. К сожалению и эти программы были реализованы не в полной мере, поскольку финансирование их либо не осуществлялось, либо осуществлялось по остаточному принципу ${ }^{2}$. В настоящее время, по-прежнему, основной проблемой государственной политики в отношении несовершеннолетних является отсутствие системной консолидированной деятельности всех существующих институтов.

В качестве координирующего органа некоторые авторы предлагают рассматривать прокуратуру, она выступает контролирующим и координирующем органом для правоохранительных органов, основным видом деятельности для которых является профилактика ${ }^{3}$

\footnotetext{
${ }^{1}$ См.: Постановление Правительства РФ от 8 октября 1998 г. № 1174 «О Межведомственной комиссии по координации работ, связанных с выполнением в РФ Конвенции ООН о правах ребенка и Всемирной декларации об обеспечении выживания, защиты и развития детей» // СЗ РФ. 1998. № 41. Ст. 5034.

${ }^{2}$ Г. А. Аванесов, Н. Д. Эриашвили. Криминологическая характеристика и предупреждение преступности несовершеннолетних // http://detstvo.edurm.ru/index.php?option=com content \&view $=$ article \&id $=144: 2013-04-17-05-06-$ 02\&catid=7:2011-07-28-09-20-58\&Itemid=7.

${ }^{3}$ Утибаев Г.К. Теоретико-прикладные проблемы координации деятельности правоохранительных органов по
}

Другие авторы говорят, что подобную координационную функцию в ряде зарубежных государств выполняет ювенальный суд ${ }^{4}$, который имеет правовые основания для требования исполнения своих решений и предписаний от всех субъектов и лиц, на которых законом возложена обязанность по воспитанию, социальной защите и профилактике правонарушений несовершеннолетних.

Однако, необходимо согласиться с важностью координации деятельности всех субъектов профилактики и передачи соответствующих функций специальному субъекту, более осведомленному в профилактической деятельности в отношении несовершеннолетних и обладающему правовыми, организационными и финансовыми средствами для реализации указанных функций.

В связи с изложенным, правильным решением вопроса будет являться передача координационных функций государственному органу, обладающему властными полномочиями по разрешению правовых вопросов в отношении несовершеннолетних - ювенальному суду.

Отечественная практика исторически складывалась таким образом, что большую часть работы по профилактике правонарушительного поведения несовершеннолетних проводилась сотрудниками органов внутренних дел. Федеральный закон от 24 июня 1999 г. № 120-Ф3 «Об основах системы профилактики безнадзорности и правонарушений несовершеннолетних» ${ }^{5}$ перечислил органы и учреждения, входящие в систему профилактики безнадзорности и правонарушений несовершеннолетних. Часть 1 ст. 4 регламентирует систему профилактики безнадзорности и правонарушений. Закон разделяет функциональные обязанности между определенными ведомствами по категориям несовершеннолетних: с подростками, которые находятся в трудной жизненной ситуации, но еще не попали в сферу уголовно-правового воздействия, работают неполицейские субъекты профилактики, а с правонарушителями - сотрудники органов внутренних дел.

предупреждению преступлений. Автореферат дисс... докт. юрид.наук.- Астана, 2007. С. 9-10.

${ }^{4}$ Савина Н.Н. Взгляд на проблему. О профилактике правонарушений и преступлений несовершеннолетних // Законы России. Опыт, анализ, практика. 2006. № 5.

${ }^{5}$ См.: Федеральный Закон от 24 июня 1999 г. № 120-ФЗ «Об основах системы профилактики безнадзорности и правонарушений несовершеннолетних» // СЗ РФ. 1999. № 26. Ст. 3177. 
Федеральный закон от 24 июля 1998 г. № 124-Ф3 «Об основных гарантиях прав ребенка в Российской Федерации» ${ }^{1}$ устанавливает основные полномочия органов государственной власти РФ в сфере защиты прав и интересов ребенка в России. Среди них следует особое место занимает установление основ федеральной политики в интересах детей; выбор приоритетных направлений деятельности по обеспечению прав и законных интересов ребенка, охраны его здоровья и нравственности; принятие федеральных законов и иных нормативных правовых актов Российской Федерации о регулировании и защите прав и свобод ребенка; установление государственных минимальных социальных стандартов основных показателей качества жизни детей; формирование и реализацию федеральных целевых программ защиты прав ребенка и поддержки детства и определение ответственных за исполнение таких программ органов, учреждений и организаций; финансирование федеральных мероприятий по реализации государственной политики в интересах детей за счет средств федерального бюджета, внебюджетных источников и иных не запрещенных законом источников; исполнение международных обязательств РФ².

Субъектами, осуществляющими профилактику асоциального поведения несовершеннолетних, на уровне оперативного профилактического воздействия на конкретные социальные группы и на уровне индивидуальной работы с несовершеннолетними, выступают специализированные органы, в первую очередь - комиссии по делам несовершеннолетних.

Комиссии по делам несовершеннолетних и защите прав (далее - комиссии) - ключевой субъект системы профилактики правонарушений несовершеннолетних, и именно в связи с этим комиссии стоят на первом месте в системе субъектов профилактики, предусмотренной ст. 4 Федерального закона от 24 июня 1999 г. № 120-Ф3 «Об основах системы профилактики безнадзорности и правонарушений несовершеннолетних». В соответствии с действующим до настоящего времени Положением о комиссиях по делам не-

\footnotetext{
${ }^{1}$ См.: Федеральный закон от 24 июля 1998 г. № 124-Ф3 «Об основных гарантиях прав ребенка в Российской Федерации» // С3 РФ. 1998. № 31. Ст. 3802.

${ }^{2}$ См.: Федеральный закон от 24 июля 1998 г. № 124-Ф3 «Об основных гарантиях прав ребенка в Российской Федерации» // СЗ РФ. 1998. № 31. Ст. 3802.
}

совершеннолетних ${ }^{3}$, утвержденном указом Президиума Верховного совета РСФСР от 3 июня 1967 г., именно комиссии должны обеспечивать функционирование единой комплексной системы предупреждения правонарушений несовершеннолетних, определять профилактический аспект деятельности входящих в нее органов и учреждений, выполнять по отношению к ним контролирующие функции. Тем не менее, большинством органов, учреждений, организаций, граждан, а зачастую и самими несовершеннолетними, решения комиссий воспринимаются только как рекомендательные. Полномочиями комиссии в соответствии со ст. 11 Федерального закона «Об основах системы профилактики безнадзорности и правонарушений несовершеннолетних» определено обеспечение:

- осуществления мер по защите и восстановлению прав и законных интересов несовершеннолетних, выявлению и устранению причин и условий, способствующих безнадзорности, беспризорности, правонарушениям и антиобщественным действиям несовершеннолетних;

- осуществления мер по координации вопросов, связанных с соблюдением условий воспитания, обучения, содержания несовершеннолетних, а также с обращением с несовершеннолетними в учреждениях системы профилактики безнадзорности и правонарушений несовершеннолетних;

- осуществления мер по координации деятельности органов и учреждений системы профилактики безнадзорности и правонарушений несовершеннолетних;

- подготовки совместно с соответствующими органами или учреждениями материалов, представляемых в суд, по вопросам, связанным с содержанием несовершеннолетних в специальных учебно-воспитательных учреждениях закрытого типа;

- $\quad$ рассмотрения представлений органа управления образовательного учреждения об исключении несовершеннолетних, не получивших основного общего образования, из образовательного учреждения и по ряду других вопросов их обучения;

- оказания помощи в трудовом и бытовом устройстве несовершеннолетних, освобо-

\footnotetext{
${ }^{3}$ См.: Указ Президиума Верховного Совета РСФСР от 3 июня 1967 г. «Об утверждении положения о комиссиях по делам несовершеннолетних» (с изм. от 25 февраля 1993 г.) // Ведомости Верховного Совета РСФСР. 1967. № 23. Ст. 536.
} 
жденных из учреждений уголовно-исполнительной системы либо вернувшихся из специальных учебно-воспитательных учреждений, содействие в определении форм устройства других несовершеннолетних, нуждающихся в помощи государства, а также осуществление иных функций по социальной реабилитации несовершеннолетних; - применения мер воздействия в отношении несовершеннолетних, их родителей или иных законных представителей.

Порядок образования комиссий по делам несовершеннолетних и защите их прав и осуществления ими отдельных государственных полномочий определяется законодательством Российской Федерации и законодательством субъектов Российской Федерации. Наконец-то, Постановлением Правительства Российской Федерации от 6 ноября 2013 г. N 995 г., усовершенствован порядок организации и деятельности комиссий по делам несовершеннолетних и защите их прав субъектов РФ. Минобрнауки России подготовлено и Правительством РФ утверждено соответствующее постановление, устанавливающее правовое положение комиссий ${ }^{1}$.

Следует отметить, что нормы, регулирующие деятельность комиссий, в частности - Примерным положением о комиссиях по делам несовершеннолетних и защите их прав (далее - Положение), устранили правовой вакуум и создали определенность в отношении правового положения и деятельности комиссий. Так, в научной литературе был спор по поводу того, являлись ли комиссии государственными органами или они относились к общественным организациям. Положение отнесло комиссии к государственным органам потому, что деятельность комиссий направлена на осуществление определенных функций государственного характера, выражающегося в праве издавать юридические акты, обязательные для исполнения, которые подкрепляются силой государственного принуждения². В настоящее время комиссии становятся своего рода административными судами, рассматривающими отдельные вопросы в сфере взаимодействия, с одной стороны, работодателей, образо-

\footnotetext{
${ }^{1}$ ИА «ГАРАНТ $:$ http://www.garant.ru/news/504100/ \#ixzz32RTaAgDc

${ }^{2}$ См.: Барахтян Н.Б. О правовой природе комиссий по делам несовершеннолетних // Проблемы совершенствования правового регулирования общественных отношений в период перестройки: Сб. науч. трудов.-Харьков, 1991. С. 159.
}

вательных учреждений, родителей, законных представителей, подростков - с другой. Кодекс РФ об административных правонарушения ${ }^{3}$ определяет подведомственность дел об административных правонарушениях несовершеннолетних, передавая их на рассмотрение в комиссии по делам несовершеннолетних и защите их прав (ст. 23.2). Именно комиссиям принадлежит преимущественное право рассмотрения дел об административных правонарушениях, совершенных несовершеннолетними. Однако в ч. 2 ст. 23.2 Кодекса делается следующее исключение: дела об административных правонарушениях, предусмотренных ст. 11.18, а также дела об административных правонарушениях в области дорожного движения рассматриваются комиссиями по делам несовершеннолетних и защите их прав в случаях, если орган или должностное лицо, к которым поступило дело о таком административном правонарушении, передает его на рассмотрение указанной комиссии.

Комиссии рассматривают дела об административных правонарушениях, предусмотренных ст. 5.35 Кодекса об административных правонарушениях, в отношении родителей или заменяющих их лиц, а также дела о нарушении порядка или сроков предоставления сведений о несовершеннолетних, нуждающихся в передаче на воспитание в семью либо в учреждение для детей-сирот или для детей, оставшихся без попечения родителей, предусмотренных ст. 5.36 Кодекса об административных правонарушениях. Таким образом, предоставление федеральным законодательством комиссиям полномочий по разрешению дел об административных правонарушениях однозначно говорит в пользу признания комиссий государственными органами.

В целях изучения и устранения причин и условий, порождающих правонарушения несовершеннолетних муниципальные комиссии подготавливают и направляют в органы государственной власти субъектов Российской Федерации и органы местного самоуправления в порядке, установленном законодательством субъектов Российской Федерации, отчеты о работе по профилактике безнадзорности и правонарушений несовершеннолетних на территории соответствующего муниципального образования (п. 7 Положения).

\footnotetext{
${ }^{3}$ Кодекс Российской Федерации об административных правонарушениях от 30 декабря 2001 г. № 195-Ф3 // СЗ РФ. 2002. № 1 (часть 1). Ст. 1.
} 
По мнению некоторых авторов, отсутствие специальной подготовки у членов комиссий приводит к тому, что проблемы социально-правовой реабилитации несовершеннолетних остаются без внимания. Так, Н.Н. Савина отмечает, что комиссии не могут оказывать должного влияния на состояние подростковой преступности ${ }^{1}$. Профессор Е. Р. Россинская также отмечает, что «при рассмотрении дел об административных правонарушениях эти субъекты также нуждаются в использовании специальных познаний, однако редко ими обладают»².

Противоположной точки зрения придерживается Л.А. Соболева. В Пермском крае в течение 2-х лет отрабатывались рабочие модели для системы профилактики социально опасного положения и правонарушения несовершеннолетних. Разработанные программы восстановительного правосудия позволяют изменить порядок работы комиссий в целях направления их деятельности на решение задач социализации несовершеннолетних, а не для их наказания и клеймения. При восстановительном подходе в работе с несовершеннолетними и их семьями используется новая схема работы комиссий: в их работе участвуют социальные работники, используются новые механизмы решения кризисных ситуаций, криминальных конфликтов - восстановительные программы, направленные на поиск конструктивного решения возникших проблем ${ }^{3}$. Дела о несовершеннолетних поступают в комиссии в своей основной массе из районных отделов внутренних дел. Секретарь комиссии вместе с социальным работником, работающим при комиссии, отбирает дела для проведения восстановительных программ. Далее совместная деятельность комиссии и социального работника складывается из нескольких этапов. На первом этапе осуществляется диагностика ситуации в семье и возможности проведения программы при-

\footnotetext{
${ }^{1}$ См.: Савина Н.Н. Взгляд на проблему. О профилактике правонарушений и преступлений несовершеннолетних // Законы России. Опыт, анализ, практика. 2006. № 5.

${ }^{2}$ Цит. по: Россинская Е.Р. Специальные познания и современные проблемы их использования в судопроизводстве // Журнал российского права. 2001. № 5. С. 43.

${ }^{3}$ См.: Соболева Л.А. О системе работы и перспективах развития системы защиты прав несовершеннолетних, ювенальной юстиции и восстановительного подхода в Пермском крае. // Официальный сайт Уполномоченного по правам человека в Пермском крае, http//uppc.perm.ru/ tribune/legal_exp.php?ncid=103-13k
}

мирения жертвы и правонарушителя. Затем результаты первого этапа обрабатываются, обсуждаются с должностным лицом комиссии, и составляется план реабилитации. Основной этап - проведение реабилитационных мероприятий, направленных на восстановление семьи (лечение от алкоголизма, устройство на работу, устройство детей в детский сад, в школу, организация психологической консультации, материальной помощи и т.д.). Завершающий этап - анализ проведенной работы на заседании комиссии с принятием окончательного решения относительно несовершеннолетнего и его семьи. Благодаря подобной технологии работы, члены комиссии принимают самое непосредственное участие в защите прав несовершеннолетнего, при этом «в процесс оценивания своих поступков, повышения ответственности за совершенное правонарушение, заглаживание вреда активно вовлекается сам несовершеннолетний» ${ }^{4}$.

Возможность преобразования комиссий для определения их места в системе органов ювенальной юстиции видится в переориентации их деятельности с функций административного воздействия и констатации факта совершенного правонарушения на создание и реализацию индивидуальных программ работы с несовершеннолетними из группы риска 5 . А для этого необходимо преобразовать комиссии в консультативный и координирующий орган профилактики правонарушений несовершеннолетних при системе исполнительной власти и местного самоуправления ${ }^{6}$, при этом полномочия в области юрисдикционной деятельности передать специальным судам по делам несовершеннолетних, в которых вопросы судебной защиты прав несовершеннолетних и юридической ответственности за совершенные ими правонарушения

\footnotetext{
${ }^{4}$ Цит.по: Соболева Л. А. О системе работы и перспективах развития системы защиты прав несовершеннолетних, ювенальной юстиции и восстановительного подхода в Пермском крае. // Официальный сайт Уполномоченного по правам человека в Пермском краe, http//uppc.perm.ru/tribune/ legal_exp.php?ncid=103-13k

${ }_{5}^{5}$ Савина Н.Н. Взгляд на проблему. О профилактике правонарушений и преступлений несовершеннолетних // Законы России. Опыт, анализ, практика. 2006. № 5 .

${ }^{6}$ См.: Николаев М. В. В Россию надо вернуть суды для несовершеннолетних // Российская юстиция. 1996. № 4. C. 57.
} 
решались бы комплексно1. Таким образом, процесс становления ювенальной юстиции в РФ не прекратит деятельности комиссий, поскольку их работа не утратит своей актуальности. Правозащитная, координирующая и контролирующая функции комиссии позволят им проводить пол- ное и объективное исследование условий жизни подростков, разрабатывать индивидуальные программы профилактики, осуществлять психологическую диагностику личности несовершеннолетних, содействовать их трудоустройству или получению образования².

\section{Библиография}

1. Барахтян Н. Б. О правовой природе комиссий по делам несовершеннолетних // Проблемы совершенствования правового регулирования общественных отношений в период перестройки: Сб. науч. трудов. - Харьков, 1991.

2. Г.А. Аванесов, Н. Д. Эриашвили. Криминологическая характеристика и предупреждение преступности несовершеннолетних. [Электронный ресурс]. - Режим доступа: http:// detstvo.edurm.ru/index.php?option $=$ com_content\&view $=$ article \&id=144:2013-04-17-05-0602\&catid=7:2011-07-28-09-20-58\&Itemid $=7$.

3. Мельникова Э.Б., Ветрова Г.Н. Российская модель ювенальной юстиции (теоретическая концепция) // Правозащитник.- 1996. - № 1.

4. Николаев М. В. В Россию надо вернуть суды для несовершеннолетних // Российская юстиция.1996. - № 4.

5. Россинская Е. Р. Специальные познания и современные проблемы их использования в судопроизводстве // Журнал российского права. - 2001. - № 5.

6. Савина Н.Н. Взгляд на проблему. О профилактике правонарушений и преступлений несовершеннолетних // Законы России. Опыт, анализ, практика. - 2006. - № 5.

7. Соболева Л. А. О системе работы и перспективах развития системы защиты прав несовершеннолетних, ювенальной юстиции и восстановительного подхода в Пермском крае. // Официальный сайт Уполномоченного по правам человека в Пермском крае.- Режим доступа: http//uppc.perm. ru/tribune/legal_exp.php?ncid=103-13k

8. Утибаев Г.К. Теоретико-прикладные проблемы координации деятельности правоохранительных органов по предупреждению преступлений. Автореферат дисс... докт.юрид.наук.— Астана, 2007.

\section{References (transliterated)}

1. Barakhtyan N. B. O pravovoi prirode komissii po delam nesovershennoletnikh // Problemy sovershenstvovaniya pravovogo regulirovaniya obshchestvennykh otnoshenii v period perestroiki: Sb. nauch. trudov. - Khar'kov, 1991.

2. G. A. Avanesov, N. D. Eriashvili. Kriminologicheskaya kharakteristika i preduprezhdenie prestupnosti nesovershennoletnikh. [Elektronnyi resurs]. - Rezhim dostupa: http://detstvo.edurm.ru/index. php?option $=$ com_content\&view $=$ article $\& i d=144: 2013-04-17-05-06-02 \&$ catid=7:2011-07-28-09-20 $58 \&$ Itemid $=7$.

3. Mel'nikova E.B., Vetrova G. N. Rossiiskaya model» yuvenal'noi yustitsii (teoreticheskaya kontseptsiya) // Pravozashchitnik. - 1996. - № 1.

4. Nikolaev M. V. V Rossiyu nado vernut» sudy dlya nesovershennoletnikh // Rossiiskaya yustitsiya. 1996. - № 4.

5. Rossinskaya E. R. Spetsial'nye poznaniya i sovremennye problemy ikh ispol'zovaniya v sudoproizvodstve // Zhurnal rossiiskogo prava. - 2001. - № 5 .

6. Savina N. N. Vzglyad na problemu. O profilaktike pravonarushenii i prestuplenii nesovershennoletnikh // Zakony Rossii. Opyt, analiz, praktika. — 2006. — № 5 .

\footnotetext{
${ }^{1}$ См.: Мельникова Э. Б., Ветрова Г.Н. Российская модель ювенальной юстиции (теоретическая концепция) // Правозащитник. 1996. № 1. С. 23.
}

\footnotetext{
${ }^{2}$ См.: Савина Н.Н. Взгляд на проблему. О профилактике правонарушений и преступлений несовершеннолетних // Законы России. Опыт, анализ, практика. 2006. № 5 .
} 
7. Soboleva L. A. O sisteme raboty i perspektivakh razvitiya sistemy zashchity prav nesovershennoletnikh, yuvenal'noi yustitsii i vosstanovitel'nogo podkhoda v Permskom krae. // Ofitsial'nyi sait Upolnomochennogo po pravam cheloveka v Permskom krae. - Rezhim dostupa: http//uppc.perm.ru/ tribune/legal_exp.php?ncid=103-13k

8. Utibaev G. K. Teoretiko-prikladnye problemy koordinatsii deyatel'nosti pravookhranitel'nykh organov po preduprezhdeniyu prestuplenii. Avtoreferat diss... dokt.yurid.nauk. — Astana, 2007. 